Urszula Ostrowska*

ORCID: 0000-0003-2280-706X

Gorzów Wielkopolski, Polska

\title{
Antropologia i pedagogika w kręgu wiedzy nauk o czlowieku. Problemy i wyzwania
}

\section{Anthropology and Pedagogy in the Field of Human Sciences. Problems and Challenges}

\begin{abstract}
Contemporary human sciences, practicing their subject of research and implementing the set goals and tasks, are more and more willing to establish interdisciplinary contacts using the scientific achievements of various disciplines supporting and expanding their own achievements and development opportunities. The beginning of our century was dominated by the 'great revolution' supported by science and its achievements, confronting man with even greater tasks to be solved and dilemmas of an unprecedented scale of complexity and problematic. Meanwhile, in the face of experiencing the insufficiency of knowledge about man, transhumanism promotes more and more projects to overcome human limitations to improve the human condition. This state of affairs presents science and education with challenges that will not be easy to face in the face of emerging dilemmas, and at the same time generates numerous key problems ad deliberandum.
\end{abstract}

Keywords: human sciences; anthropology; pedagogy; problems; challenges.

* Prof. dr hab. Urszula Ostrowska, Wydział Humanistyczny, Akademia im. Jakuba z Paradyża w Gorzowie Wielkopolskim, email: urszula.ostrowska@wp.pl. 


\begin{abstract}
Abstrakt: Spektrum dyscyplin naukowych zajmujących się człowiekiem i jego światem jest dość różnorodne w swoim bogactwie. Jednakże w dotychczasowych osiągnięciach nauki wiedza o człowieku spośród wszystkich rodzajów wiedzy wzbudza największy niedosyt. Współczesne nauki o człowieku, uprawiając swój przedmiot badań oraz realizując wytyczone cele i zadania, coraz chętniej nawiązują interdyscyplinarne kontakty korzystając z dorobku naukowego różnych dyscyplin wspomagających i poszerzających swoje własne osiągnięcia oraz możliwości rozwoju. Początek naszego stulecia zdominowany został przez „wielką rewolucję” wspieraną przez naukę i jej osiągnięcia stawiające człowieka wobec jeszcze większych zadań do rozwiązania oraz dylematów o niespotykanej dotąd skali złożoności i problematyczności. Tymczasem w obliczu doświadczania niedosytu wiedzy o człowieku coraz odważniej lansowane są przez transhumanizm przedsięwzięcia w zakresie przezwyciężenia ludzkich ograniczeń w celu poprawy / „ulepszania” kondycji ludzkiej. Ów stan rzeczy stawia przed nauką i edukacją wyzwania, którym w obliczu rodzących się dylematów niełatwo będzie stawić czoła, a przy tym generuje liczne kluczowe problemy ad deliberandum.
\end{abstract}

Słowa kluczowe: nauki o człowieku; antropologia; pedagogika; problemy; wyzwania.

\title{
1. Uwagi wstępne
}

Nauka - obok techniki i sztuki oraz religii, a także innych preferowanych przez ludzi dziedzin życia - zaliczana jest współcześnie do priorytetowych sfer działalności ludzkiej. Od zarania dziejów ludzie pragnęli wzbogacać swoją wiedzę o otaczającej rzeczywistości w toku podejmowania prób jej wnikliwego poznawania i doskonalenia w celu lepszego rozumienia świata, a także czynienia go bardziej użytecznym i przyjaznym dla człowieka. Spośród funkcjonujących gatunków wiedzy ludzkiej, takich zwłaszcza jak potoczna, naukowa, teologiczna, artystyczno-literacka, spekulatywna, irracjonalna, pierwsza $\mathrm{z}$ tu wymienionych - wiedza naukowa - uznawana jest za najlepszą pod względem poznawczym, najbardziej adekwatnie opisującą rzeczywistość z racji wykorzystywanych w jej uprawianiu metod oraz posługiwania się językiem naukowym, a także stosowania wobec niej odpowiednich procedur, w tym takich rygorów jak intersubiektywna komunikowalność oraz intersubiektywna kontrolowalność/weryfikowalność, jak również praktykowania innych typowych dla życia naukowego funkcjonujących w nim 
form w postaci publikacji, recenzji, debat, konferencji, seminariów, polemik, dyskursów. Nie bez racji przeto filozof i logik, reprezentant szkoły lwowsko-warszawskiej, Kazimierz Ajdukiewicz (1890-1963), postrzegał naukę jako „skarbnicę” i następująco uzasadniał cenienie jej jako wartości najwyższego wymiaru, która jego zdaniem ,jest skarbnicą najlepiej uzasadnionej i najjaśniej sformułowanej wiedzy ludzkiej. Jeśli wiedza posiada jakąkolwiek wartość, to wartość tę w najwyższym stopniu posiada nauka" (Ajdukiewicz, 1960, s. 314). Toteż nic dziwnego, że osiągnięcia naukowe stanowiące podstawę dla postępu w różnych dziedzinach życia niezmiennie z jednej strony wzbudzają podziw, zachwyt i uznanie dla ich twórców, z drugiej strony zarazem inspirująco skłaniają ku podejmowaniu dalszych niekończących się przedsięwzięć w tym obszarze.

\section{Nauki o czlowieku w systematyce nauk}

W rezultacie intensywnego rozwoju nauki przybiera ona postać fenomenu coraz bardziej złożonego i wieloaspektowego, toteż zazwyczaj artykułowane są takie ważniejsze aspekty tej sfery działalności ludzkiej, jak historyczno-geograficzny, statyczny, dynamiczny, treściowy, metodologiczny, strukturalny, językowy, aksjologiczny, semiotyczny, psychologiczny, socjologiczny, teologiczny, organizacyjny, prawny, ideologiczny, polityczny, ekonomiczny oraz inne. Taki stan rzeczy o narastającej złożoności rzecz jasna wymaga porządkujących podejść do nauki, w toku których to zabiegów wprowadzane są - w zależności od przyjętych kryteriów oraz wytyczonych celów - rozmaite podziały nauk, w tym wyodrębnia się obszary, dziedziny, dyscypliny i subdyscypliny naukowe. W najnowszej klasyfikacji dziedzin i dyscyplin naukowych obowiązujących w Polsce - stosowanej w organizacji badań, klasyfikacji dziedzin stopni naukowych i kierunków nauczania w uczelniach wyższych, a także wykorzystywanych w celach statystycznych - na mocy Rozporządzenia Ministra Nauki i Szkolnictwa Wyższego z dnia 20 września 2018 roku $^{1}$ wprowadzony został dwustopniowy podział na dziedziny nauk i przypisane im dyscypliny naukowe. W niniejszym rozporządzeniu wyłoniono osiem dziedzin nauk, tj.: nauk humanistycznych, nauk społecznych, nauk ścisłych i przyrodniczych, nauk medycznych i nauk o zdrowiu, nauk

${ }^{1}$ Rozporządzenie Ministra Nauki i Szkolnictwa Wyższego z dnia 20 września 2018 r. w sprawie dziedzin nauki i dyscyplin naukowych oraz dyscyplin artystycznych (Dz.U. 2018, poz. 1818). 
inżynieryjno-technicznych, nauk rolniczych, nauk teologicznych oraz dziedzina sztuki. Spośród nich, cztery pierwsze w kolejności tu wymienionych dziedzin zazwyczaj postrzegane są jako kluczowe w zakresie dostarczania wiedzy o człowieku i jego świecie.

Wcześniej w Polsce, tj. w latach 2011-2018 na mocy Rozporządzenia Ministra Nauki i Szkolnictwa Wyższego z dnia 8 sierpnia 2011 roku w sprawie obszarów wiedzy, dziedzin nauki i sztuki oraz dyscyplin naukowych i artystycznych obowiązywała systematyka trójstopniowa ${ }^{2}$. Uwzględniono w niej bowiem - oprócz dziedzin nauki, a w ich obrębie dyscyplin naukowych również odpowiednio im przypisane obszary wiedzy.

Wypada jeszcze dodać, że w latach 2005-2011, zgodnie z uchwałami Centralnej Komisji do Spraw Stopni i Tytułów ${ }^{3}$ stosowana była systematyka dwustopniowa - dziedzinom nauki i dziedzinom sztuki przypisano wchodzące w ich skład dyscypliny naukowe i artystyczne.

Nietrudno zauważyć, że owo spektrum dyscyplin naukowych przypisanych wskazanym powyżej czterem dziedzinom nauk zazwyczaj postrzeganych jako kluczowe w zakresie dostarczania wiedzy o człowieku i jego świecie jest dość bogate 4 . Jednakże w obu tych klasyfikacjach wprowadzonych na mocy Rozporządzeń Ministra Nauki i Szkolnictwa Wyższego (lata 2011-2018 - systematyka trójstopniowa i od 2018 roku - systematyka dwustopniowa), a także w poprzedzającej je zgodnie z uchwałami Centralnej Komisji do Spraw Stopni i Tytułów stosowanej w latach 2005-2011 dwustopniowej

${ }^{2}$ Rozporządzenie Ministra Nauki i Szkolnictwa Wyższego z dnia 8 sierpnia $2011 \mathrm{r}$. w sprawie obszarów wiedzy, dziedzin nauki i sztuki oraz dyscyplin naukowych i artystycznych (Dz.U. $2011 \mathrm{Nr}$ 179, poz. 1065).

${ }^{3}$ Uchwała Centralnej Komisji Do Spraw Stopni i Tytułów z dnia 24 października 2005 r. w sprawie określenia dziedzin oraz dyscyplin naukowych i artystycznych (M.P. $2005 \mathrm{Nr} 79$, poz. 1120); Uchwała Centralnej Komisji do Spraw Stopni i Tytułów z dnia 10 grudnia 2008 r. zmieniająca uchwałę w sprawie określenia dziedzin nauki i dziedzin sztuki oraz dyscyplin naukowych i artystycznych (M.P. $2008 \mathrm{Nr}$ 97, poz. 843).

${ }^{4}$ Oto owe dziedziny i przypisane dyscypliny naukowe: dziedzina nauk humanistycznych - dyscypliny: archeologia, filozofia, historia, językoznawstwo, literaturoznawstwo, nauki o kulturze i religii, nauki o sztuce; dziedzina nauk społecznych - dyscypliny: ekonomia i finanse, geografia społeczno-ekonomiczna i gospodarka przestrzenna, nauki o bezpieczeństwie, nauki o komunikacji społecznej i mediach, nauki o polityce i administracji, nauki o zarządzaniu i jakości, nauki prawne, nauki socjologiczne, pedagogika, prawo kanoniczne, psychologia; dziedzina nauk ścisłych i przyrodniczych - dyscypliny: astronomia, informatyka, matematyka, nauki biologiczne, nauki chemiczne, nauki fizyczne, nauki o Ziemi i środowisku; dziedzina nauk medycznych i nauk o zdrowiu - dyscypliny: nauki farmaceutyczne, nauki medyczne, nauki o kulturze fizycznej, nauki o zdrowiu. 
klasyfikacji, obejmującej swym zakresem dziedziny nauki i dziedziny sztuki oraz wchodzące w ich skład dyscypliny naukowe i artystyczne, nie ujęto antropologii ${ }^{5}$.

Tymczasem właśnie antropologia (z gr. ő $v \theta \rho \omega \pi \circ \varsigma$ - ,człowiek” i $\lambda o ́ \gamma o \varsigma-$ „nauka”) będąca interdyscyplinarną nauką sytuującą się na pograniczu nauk humanistycznych, społecznych i przyrodniczych zajmuje się badaniem człowieka jako jednostki w społeczeństwie w kontekście historycznej zmienności oraz z perspektywy uwarunkowań socjalno-ekonomicznych i kulturowych. Wyłoniono w niej dwa podstawowe nurty, a mianowicie: antropologię fizyczną zajmującą się zmiennością biologiczną i fizjologiczną człowieka oraz antropologię kulturową, która zajmuje się człowiekiem sytuowanym w społeczności, osobą egzystującą w różnych zbiorowościach społecznych czasem określa się ten nurt jako antropologia społeczna. Natomiast z uwagi na przedmiot badań oraz obszary zainteresowań wyróżniane są coraz liczniejsze działy antropologii, w tym takie, jak: antropologia religii/religijna, antropologia edukacji, antropologia wychowania, antropologia pedagogiczna, antropologia słowa, antropologia wizualności, antropologia widowisk, antropologia ciała, antropologia polityczna, antropologia organizacji, antropologia sportu, antropologia sztuk i inne.

W obliczu doświadczanego dotkliwie niedosytu wiedzy o człowieku, zważywszy zwłaszcza przedmiot zainteresowań antropologii, poniekąd może zdumiewać fakt pominięcia $\mathrm{w}$ funkcjonującej w Polsce systematyce nauk tejże dyscypliny, której już sama nazwa orzeka ewidentnie, że jest to nauka o człowieku. Niewykluczone, że taki stan rzeczy może również niejako sugerować, iż zajmowanie się kwestią człowieka naukowo, jak również koncentrowanie uwagi na problemach dotyczących człowieka, nie jest aż tak bardzo ważne tudzież konieczne czy pożądane, albowiem każdy człowiek, zwłaszcza dorosły, doskonale wie, jaki jest i co jest dla niego najlepsze, intuicyjnie domyśla się, jak ma postępować i orientuje się, co powinien preferować w swoim życiu, a co kontestować czy też zdecydowanie potępiać i odrzucać. Konsekwencje takiego stanu rzeczy mogą prowadzić niechybnie do uznania, iż człowiek jest zwolniony z interesowania się samym sobą oraz z powinności wnikliwego poznawania samego siebie, tudzież dbania o swój status quo, o swoje człowieczeństwo, jak również nie ma istotnych obowiązków wobec siebie samego i innych, w tym nie musi zajmować stanowiska

${ }^{5}$ Por. Rozporządzenie Ministra Nauki i Szkolnictwa Wyższego z dnia 20 września 2018 r. w sprawie dziedzin nauki i dyscyplin naukowych oraz dyscyplin artystycznych (Dz.U. 2018, poz. 1818). 
dotyczącego występujących wśród ludzi i z ich przyczyny różnorodnych nieprawidłowości, jak też angażować się w kreowanie procesów własnego rozwoju i doskonalenia jako osoby. Bez wątpienia uznanie, że człowiek nie ma nic do uczynienia w tychże kwestiach po prostu zamyka mu drogę do jakiegokolwiek rozwoju i postępu oraz zmian i doskonalenia siebie samego, a także otaczającej rzeczywistości.

\section{Drogi i bezdroża kwestii dociekania, kim jest czlowiek}

Niemniej w toku dziejów wielokrotnie uzasadniano konieczność dociekania kwestii, kim jest człowiek, w tym niejednokrotnie sygnalizowano nieodzowność podejmowania przez ludzi trudu zwracania się ku sobie i wni-

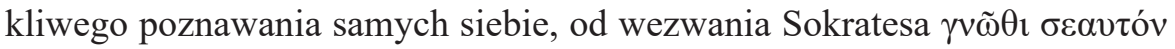
poczynając, które w thumaczeniu na język łaciński brzmi nosce te ipsum. Maksyma ta wyryta na frontonie świątyni Apollina w Delfach niestety pozostała w swej spetryfikowanej postaci, nie doczekawszy się powszechnego urzeczywistnienia nie tylko w czasach antycznych. Także w kolejnych stuleciach naszej ery do absolutnych wyjątków należało wnikliwe i systematyczne oraz odpowiedzialne skłanianie się ku temu zadaniu i wezwaniu.

Nietrudno zorientować się, że na przestrzeni dziejów w przedsięwzięciach epistemologiczno-eksploracyjnych dominuje orientacja na poznawanie otaczającej rzeczywistości, w której człowiek niejako jest pomijany, spychany na drugi plan, a nawet ,gubiony po drodze”, tudzież „omijany” - jak to określił św. Augustyn z Hippony (354-430), filozof, teolog, myśliciel uprawiający również refleksję pedagogiczną oraz organizator życia kościelnego. Ów stan rzeczy wzbudzał niepokój autora dzieł należących do światowej klasyki literatury duchowej. Opisywane wydarzenia z własnego życia w swoim najsłynniejszym dziele zatytułowanym Wyznania, składającym się z 13 ksiąg napisanych pomiędzy 397 a 401 rokiem, filozof ujął w postaci teorii człowieka pokonującego drogę od sceptycyzmu, poprzez manicheizm, aż do chrześcijaństwa. Kreując tę bogatą w swej różnorodności i złożoności oraz konteksty drogę wyrażał zdumienie, że ludzie podziwiają rzeczywistość - świat, w którym żyją, w tym „,szczyty gór, spiętrzone fale morza, szeroko rozlane rzeki, Ocean otaczający ziemię, obroty gwiazd" (Augustyn, 2000, s. 272), ale niestety siebie w tejże rzeczywistości, której sami są istotną cząstką - jak się wyraził - „omijają”.

Wspomniane wcześniej wezwanie Sokratesa, któremu przypisuje się miano „ojca pedagogiki”, nie stało się wszakże urzeczywistnianym przesłaniem 
także dla kolejnych pokoleń. Oto bowiem po wiekach od jego zainicjowania francuski matematyk, fizyk i filozof religii Blaise Pascal (1623-1662) wnikliwie rozważający kwestie dotyczące człowieka w swoim nieukończonym dziele (wydano je pośmiertnie), które w zamyśle stanowić miało jednolitą i kompletną analizę oraz obronę chrześcijaństwa, eksponując nieprzeniknioną tajemnicę człowieka, zastanawiał się następująco:

Ostatecznie bowiem, czymże jest człowiek w przyrodzie? Nicością wobec nieskończoności, wszystkim wobec nicości, pośrodkiem między niczym a wszystkim. Jest nieskończenie oddalony od rozumienia ostateczności; cel rzeczy i ich początki są dlań na zawsze pokryte nieprzeniknioną tajemnicą; zarówno niezdolny jest dojrzeć nicości, z której go wyrwano, jak nieskończoności, w której go utopiono (Pascal, 2003, s. 20).

W ślad za tym odnosząc się w swoich Myślach do nieodzowności „studiowania człowieka" z goryczą orzekł:

Spędziłem długi czas na zgłębianiu nauk oderwanych: ale zbyt mała okazja do wymiany myśli zmierziła mnie. Kiedy zabrałem się do studiowania człowieka, przekonałem się, że te nauki oderwane nie są dlań stworzone i że dalej zbłąkałem się od mej natury, wnikając w nie, niż inni - nie znając ich. Przebaczyłem innym ich nieznajomość, ale sądziłem bodaj, iż znajdę wielu towarzyszy w studiowaniu człowieka i że to jest jemu przyrodzona wiedza. Omyliłem się; jeszcze mniej ludzi studiuje tę wiedzę niż matematykę. Jedynie z braku zdatności do tego studium ludzie dociekają innych rzeczy [wyr. - U.O.]; ale czyż nieprawda, że i to nie jest wiedza, która zda się człowiekowi, i że lepiej jest dlań nie znać siebie, aby być szczęśliwym? (tamże, s. 44).

Istotnie, przyznać trzeba, że z jednej strony nauka z różnych przyczyn nie jest $\mathrm{w}$ stanie odpowiedzieć satysfakcjonująco na pytanie, kim jest człowiek, skoro z rozmaitych powodów nie jest skłonna systematycznie i wnikliwie dociekać owych kwestii, z drugiej strony niewielu ludzi skłania się ku zgłębianiu tego, kim w istocie swej są. W rezultacie owego stanu rzeczy wyłania się wizerunek człowieka jako osoby skutecznie wymykającej się niemal wszelkim zabiegom epistemologiczno-eksploracyjnym, istoty ludzkiej, której nie można gruntownie rozszyfrować, toteż człowiek pozostaje w znacznej mierze zarówno dla samego siebie, jak i dla innych ludzi nie do zgłębienia tajemnicą tudzież trudną do odgadnięcia zagadką. Nic przeto dziwnego, że duński filozof, poeta romantyczny i teolog, uznawany za jednego z prekur- 
sorów filozofii egzystencjalnej, zwłaszcza jej chrześcijańskiego nurtu, Søren Aabye Kierkegaard (1813-1855), doszedł do przekonania, iż człowiek jest zagadką ,nie tylko dla innych, ale i dla siebie samego" (1996, s. 27).

Natomiast Helmuth Plessner (1892-1985), filozof i socjolog niemiecki, przedstawiciel neokantowskiej szkoły badeńskiej i jeden z głównych przedstawicieli antropologii filozoficznej konstruowanej przez niego w kontekście dwóch płaszczyzn: biologicznej i duchowej, ową „zagadkę” dookreślił przypisując jej znamię „ostatecznej” oraz nadał kosmiczny wymiar w postaci „uniwersum” następująco: „człowiek sobie samemu ani najbliższy, ani najdalszy, a jednocześnie zarówno w swojskości swej istoty najbliższy, jak i najdalszy - jest ostateczną zagadką universum [wyr. - U.O.]" (Plessner, 1994, s. 115).

Z kolei filozof niemiecki, przedstawiciel fenomenologii, Max Scheler (1874-1928), uwyraźniając kwestię poszerzania się i pogłębiania się wiedzy o świecie, zwrócił uwagę, że w sposób paradoksalny dystansuje ona do bardzo skromnego wymiaru zasoby wiedzy na temat człowieka i w związku z tym tak oto skonstatował: „W historii trwającej około 10 tysięcy lat jesteśmy pierwszą epoką, w której człowiek całkowicie i bez reszty stał się «problematyczny» [wyr. - U.O.], w której już nie wie, czym jest, a zarazem też wie, że tego nie wie” (Scheler, 1987, s. 151). Uznawany za „ojca” współczesnej antropologii filozoficznej, poszukując odpowiedzi na pytanie „czym jest człowiek i jakie zajmuje metafizyczne miejsce i położenie w obrębie całości bytu, świata oraz wobec Boga" (tamże, s. 3), koncentrował swoją uwagę zwłaszcza na wykryciu istoty człowieka jako osobowości duchowej, która zwraca się ku sobie oraz transcenduje świat jako ,poszukiwacz Boga”. Dowodził, że człowiek jest istotą, która nigdy nie zadowala się otaczającą rzeczywistością, toteż zawsze cechuje ją pragnienie przełamywania granic swego istnienia (tamże, s. 104). Poszukując jednoznacznej definicji człowieka doszedł do przekonania, że żadne dotychczasowe definicje nie są w stanie oddać jego istoty, ponieważ nie da się zdefiniować wieloaspektowości istoty ludzkiej.

Podążając w swoich rozważaniach analogicznym tropem, francusko-niemiecki (alzacki) teolog i duchowny luterański, filozof, organista, muzykolog, lekarz, laureat Pokojowej Nagrody Nobla (1952), Albert Schweitzer (1875-1965), w autobiograficznej rozprawie stwierdził, że w świecie dominującego „ducha powierzchowności” drugą naturą człowieka jest jego bezmyślność, która czuwa nad tym, aby jego myśli i mowa nie wyszły poza ramy ogólnikowych uwag i tak oto pisał na ten temat: „wszelkie myślenie (które prowadzi do innych rezultatów), o którym ludzie twierdzą, że prowadzi 
do sceptycyzmu albo do życia bez etycznych ideałów, nie jest myśleniem, lecz pod pozorem myślenia występującą bezmyślnością" (Schweitzer, 1981, s. 165). Przewodnią myślą jego osobistej filozofii była idea szacunku dla życia i wynikająca z niej koncepcja etyki czci dla życia (Ethik der Ehrfurcht vor dem Leben). Tę koncepcję uznawał on za swój autorski, najważniejszy i największy wkład w rozwój cywilizacji i ludzkości.

Obawy Schweitzera podzielało dość liczne grono myślicieli zaniepokojonych pogłębiającą się przepaścią między cywilizacją techniczną a kulturą duchową, w tym między innymi Karl Jaspers, Gabriel Marcel, Roman Ingarden i wielu innych. $Z$ uwagi wszakże na ograniczoność miejsca nie sposób odnieść się wyczerpująco do owego spektrum stanowisk, toteż z konieczności wypada decydować się na wybiórcze podejście do rozważanych kwestii w obszarze podjętej problematyki. Niemniej jednak trzeba stwierdzić, że podejmujący owe zagadnienia myśliciele w rozmaity sposób wyrażając swoje zaniepokojenie i obawy dotyczące sygnalizowanych w niniejszym tekście kwestii, w istocie swej artykułowali z różnej perspektywy problemowej i sytuowali w różnorodnych kontekstach nie tylko niedosyt wiedzy o człowieku, ale wręcz - jak można to określić - ów „głód wiedzy” antropologicznej szczególnie dotkliwie odczuwany przez reprezentantów dyscyplin zajmujących się człowiekiem, w tym, rzecz jasna, pedagogiki i antropologii. Można wszakże postrzegać ów stan rzeczy przez pryzmat szerszej perspektywy problemowej, a mianowicie jako sygnalizowanie kluczowych dla ludzkości problemów oraz zadań i wychodzenie naprzeciw konstruowanym, niecierpiącym zwłoki wyzwaniom znamiennie kierowanym pod adresem wszystkich dyscyplin naukowych zajmujących się człowiekiem, od których w szczególności oczekuje się wzbogacania zasobów tego typu wiedzy. Wprawdzie poniekąd trzeba przyznać rację szkockiemu filozofowi, historykowi i ekonomiście Dawidowi Hume'owi (1711-1776), który uzasadniał, że w istocie swej wszystkie nauki zajmują się człowiekiem i de facto są naukami o człowieku. Przy czym jednak wskazywał on zarazem na występujące w tej mierze dystynkcje, a mianowicie stwierdził, że niektóre nauki zajmują się człowiekiem bezpośrednio, inne natomiast czynią to w sposób pośredni. W jednym z zaliczanych do jego największych dzieł - Traktacie o naturze ludzkiej, wychodząc z założenia, iż nauka o człowieku jest jedyną solidną podstawą dla innych nauk, pisał na ten temat:

Jest rzeczą oczywistą, że wszystkie nauki pozostają w pewnym stosunku, bardziej lub mniej wyraźnym, do natury ludzkiej; i że choćby która z nich nie wiedzieć jak wydawała się oddalona od tej natury, to przecież wszystkie one 
powracają do niej na tej czy innej drodze. Nawet matematyka, filozofia naturalna i religia naturalna w pewnej mierze zależą od nauki o człowieku; są one bowiem przedmiotem ludzkiego poznania i są przedmiotem sądów, które tworzy człowiek dzięki swym siłom i władzom. Nie podobna orzec, jakie zmiany i udoskonalenia moglibyśmy poczynić w tych naukach, gdybyśmy gruntownie znali zakres i moc rozumu ludzkiego i gdybyśmy mogli wyjaśnić naturę tych idei, którymi się posługujemy oraz naturę tych operacji, których dokonujemy w naszych rozumowaniach. Na te udoskonalenia jeszcze bardziej należy pokładać nadzieję w religii naturalnej, jako że nie zadowala się ona tym, iż nas poucza o naturze sił wyższych, lecz sięga swoim wzrokiem dalej, do postawy, jaką te siły zajmują w stosunku do nas i do naszych obowiązków względem tych sił; wobec czego my nie tylko jesteśmy istotami, które rozumują, lecz również jednym z przedmiotów, których dotyczy nasze rozumowanie (Hume, 1963, s. 5).

Podejmował tego typu wyzwania także Gabriel Honoriusz Marcel (1889-1973), francuski filozof, myśliciel religijny, wykładowca, dramaturg, krytyk literacki oraz współtwórcza egzystencjalizmu chrześcijańskiego i jeden z głównych jego przedstawicieli. Marcelowi przypisuje się zainicjowanie współczesnego mu egzystencjalizmu z tej racji, że swoje prace opublikował on wcześniej od Martina Heideggera i Karla Jaspersa czy Jeana Paula Sartre'a, z którymi nota bene niejednokrotnie wdawał się w dość żywą polemikę. Odwołując się do doświadczenia, Marcel głównym przedmiotem zainteresowania filozofii uczynił osobę ludzką. Człowiekowi przypisał miano wędrowca - homo viator (Marcel, 1984), który w trudach życia ustawicznie zdąża do pełni człowieczeństwa. Uwrażliwiając na rozróżnianie między istnieniem i posiadaniem (Marcel, 1962) oraz między problemem i tajemnicą, zakwalifikował do tajemnic pytania dotyczące tego, co niepoznawalne, tj. wolność, zło, istnienie Boga, itp. (Marcel, 1987). W jego interpretacji wiara, nadzieja i miłość, a także wolność i świadectwo, mają dla ludzkiej egzystencji wymiar ontyczny, toteż umożliwiają człowiekowi doświadczanie transcendencji (Marcel, 1995).

Próby wychodzenia naprzeciw owym problemom i wyzwaniom ewidentnie inicjował także niemiecki psychiatra i filozof, jeden z głównych przedstawicieli egzystencjalizmu, Karl Jaspers (1883-1969), pomysłodawca ujęcia człowieka w jego całości z uwzględnieniem licznych płaszczyzn ludzkiego bytowania oraz kontekstów różnych aspektów jego egzystencji. Twierdził, że człowiek jest zawsze czymś więcej niż tym, co o sobie samym wie i czym w ogóle jest (Jaspers, 1990, s. 34). Przemyślenia Jaspersa wpisujące się w próby zrozumienia współczesnej mu sytuacji filozoficznej i duchowej człowie- 
ka, nasyconej sceptycyzmem w postaci „nieobecności Boga” w kontekście transcendentnego horyzontu egzystencji człowieczej, doprowadziły autora do przekonania o niemożności pozyskania wiedzy wyczerpującej byt ludzki. Oto bowiem twierdził on na ten temat, że

zyskano już znaczną wiedzę, której cechę zasadniczą stanowi to, że każde poznanie jest cząstkowe - także poznanie względnych całości; wyniki poznania są rozproszone - nie składają w jeden skończony obraz. Dlatego poznanie to staje się fałszywe zawsze, gdy prowadzi do totalnych sądów o bycie człowieka, do rzekomo pewnej całościowej wiedzy (Jaspers, 1999, s. 42).

Według jednego z najwybitniejszych polskich filozofów, fenomenologa, ontologa i eseisty Romana Ingardena (1983-1970), w uznaniu dla wyjątkowości dzieł i postawy którego Sejm RP ustanowił miniony rok 2020 Rokiem Ingardena - osobliwe miejsce w świecie oraz głęboko tragiczny los człowieka wynika stąd, że jego życie usytuowane jest na granicy dwu dziedzin bytu, a mianowicie przyrody i specyficznie ludzkiego świata. Filozof zwracał uwagę, że będąc istotą biologiczną, człowiek żyje na łonie przyrody, jednakże z racji swej szczególnej istotowości, przekracza owe granice ,,ale nigdy nie może w pełni zaspokoić swej wewnętrznej potrzeby bycia człowiekiem" (Ingarden, 1987a, s. 17). Eksponując pozostawanie przez człowieka tajemnicą w ogóle, a w szczególności dla samego siebie, stwierdził w tej kwestii następująco:

można powiedzieć, że prawie nie znamy siebie w swej ostatecznej, konstytutywnej naturze indywidualnej, że jesteśmy samym sobie niemal obcy [...] Nie rozumiemy siebie [...] nawet wtedy, gdy w pewnych fazach naszego życia odsłania się nam nasza natura indywidualna, bo ta natura właśnie jest dla nas czymś bardzo obcym, niemal niesamowitym w swej pierwotności i jedynym. Jeśli odsłania się nam na moment, stajemy zdumieni, oniemiali, że właśnie tacy jesteśmy (Ingarden, 1987b, s. 147).

Na kanwie owych rozważań zdecydowanie wyrażał stanowisko, że nie sposób wyjaśnić właściwej struktury człowieka bez powrotu do tradycyjnej teorii władz duszy, albowiem nie wystarczy w tej mierze bazować tylko na siłach psychicznych.

Na zakończenie tej części rozważań warto jeszcze przywołać stanowisko Georga Hansa Gadamera (1900-2002) niemieckiego filozofa, humanisty, historyka, filologa i współtwórcy XX-wiecznej hermeneutyki filozoficz- 
nej, autora rozprawy o kluczowym znaczeniu dla zrozumienia współczesnej filozofii pt. Prawda i metoda (2004), upatrującego główne źródło wiedzy o człowieku w wielości oraz różnorodności świadectw kulturowych:

olbrzymie bogactwo wiedzy o człowieku spływa na każdego z nas z przekazu tradycji, ludzkiej kultury, z poezji, ze sztuki w ogóle, z filozofii, historiografii i innych nauk historycznych. Taka wiedza jest na pewno „subiektywna”, tzn. w dużym stopniu niekontrolowana i niestabilna. Zarazem jednak jest to wiedza, której nie można odmówić uwagi, przez co od dawien dawna, od czasów „praktycznej filozofii” Arystotelesa, aż do romantycznej i postromantycznej ery tzw. nauk o duchu, przekazywana była bogata wiedza o człowieku (Gadamer, 2008, s. 39).

\section{Konstytutywne podstawy oraz wymiary współpracy nauk o czlowieku}

Współczesne nauki o człowieku, uprawiając swój przedmiot badań oraz realizując wytyczone cele i zadania, coraz chętniej nawiązują interdyscyplinarne kontakty, korzystając $\mathrm{z}$ dorobku naukowego różnych dyscyplin wspomagających i poszerzających swoje własne osiągnięcia oraz możliwości rozwoju. Równolegle z procesem dzielenia wiedzy na dyscypliny i subdyscypliny naukowe postępuje przeciwny trend w postaci integracji i jednoczenia się dyscyplin naukowych, których reprezentanci z uwagi na złożoność podejmowanych do rozwiązania problemów scalają swoje działania w tej mierze. Toteż ważną rolę w konstruowaniu, podejmowaniu i rozwiązywaniu współczesnych problemów naukowych pełni nie tylko owa interdyscyplinarna współpraca polegająca na wykorzystywaniu dorobku nauk współdziałających, lecz także wychodzenie poza wyznaczone granice teoretyczno-metodologiczne poszczególnych dyscyplin naukowych i konstruowanie interdyscyplinarnych/multidyscyplinarnych zespołów badawczych integrujących reprezentantów co najmniej dwóch, a w przypadkach uzasadnionych więcej dyscyplin naukowych, gremiów powoływanych w celu wieloaspektowego i dogłębnego eksplorowania problemów badawczych, które swoją złożonością „wykraczają” poza granice wiedzy każdej dyscypliny z osobna. Specjaliści różnych dyscyplin naukowych, tworzących owe gremia, wspólnie orientują się na poszukiwanie wzajemnych zależności i związków między zjawiskami badanymi, wykorzystując różnorodne, ale właściwe swym dys- 
cyplinom instrumentarium terminologiczne oraz funkcjonujące teorie jak również stosowane procedury badawcze.

Natomiast osiągnięcie wyższego stadium interdyscyplinarności, tj. poziomu/statusu transdyscyplinarności - czyli połączenia wszystkich dyscyplin zajmujących się człowiekiem w jedną całościową naukę o człowieku w sensie zmiany statusu epistemologiczno-eksploracyjnego poszczególnych nauk - zdaje się być niezwykle trudne do osiągnięcia. Niemniej należy dostrzegać ogromny potencjał w łamaniu owych granic dyscyplinowych i otwieraniu się na podejście interdyscyplinarne/multidyscyplinarne $\mathrm{w}$ tej mierze, choć w literaturze przedmiotu aspirowanie do takiego stanu rzeczy nie bez racji bywa sprowadzane do roszczenia iluzorycznego. Oto bowiem rozważając kwestię pedagogiki filozoficznej jako ruchu transdyscyplinarnego Krzysztof Maliszewski pojmuje transdyscyplinarność jako nową interdyscyplinarną formułę na rzecz jedności wiedzy, ale zastrzega zarazem, że

perspektywa transdyscyplinarna uświadamia iluzoryczność roszczenia do pełnego opanowania chociażby jednej dyscypliny - zawsze polifonicznej, sieciowo powiązanej z wszystkimi innymi i otwartej na przekształcenia. W sytuacji nieuchronnego wykluczenia - nawet wybitnych uczonych $-\mathrm{z}$ wielkich połaci niezmierzonego obszaru dziedzictwa kulturowego (w tym również rozmaitych wątków macierzystej specjalności), troska o jedność wiedzy i całościowy obraz człowieka wymaga zmiany poziomu aktywności badawczej. Już nie sumowanie wiedzy o jednym wchodzi $\mathrm{w}$ grę, lecz punktowe pogłębianie i nasycanie różnicą zagadnienia przez t r a n s 1 o k a c j ę kategorii, teorii i tekstów, z myślą o jakiejś zasadzie łączącej, o energetycznym arché, które ze zbioru elementów, sił i wymiarów tworzy całość. Transdyscyplinarność - przemieszczając dyskurs ponad tradycyjnymi naukami - szuka strukturalnych perspektyw, punktów widzenia pozwalających ustalać sensowne konstelacje znaczeń, a tym samym jednocześnie: 1) wzbogacać (wtórnie) wiele dyscyplin naraz, 2) ustanawiać metadyscyplinarny poziom wiedzy. Skoro nie sposób wyczerpująco poznać tradycji nawet jednej nauki, trzeba punktowo i głębinowo poznawać wyróżnione miejsca (klasyczne, perwersyjne, zapomniane, etc.) różnych pól w poszukiwaniu analogii, synaps, relacji. Wszak w dialektycznej perspektywie całość to nie jest suma rzeczy, lecz ich zasadnicza jedność (sieć powiązań w zróżnicowaniu) (Maliszewski, 2016, s. 24).

Tymczasem podstawę pedagogiki ściśle związanej z takimi dyscyplinami filozoficznymi, jak antropologia oraz aksjologia i etyka, stanowi zawsze 
jakieś rozumienie człowieka wypracowane przez antropologię oraz koncepcje wartości, a także koncepcje moralności ustalane przez etykę, poza którymi proces edukacji w żaden sposób spełniony być nie może. $\mathrm{Z}$ tego też powodu pedagogika jest traktowana jako pochodna poglądów filozoficznych. Pedagog, historyk dziejów wychowania, oświaty i myśli pedagogicznej, pedeutolog Stefan Wołoszyn (1911-2004) wyrażał następujące stanowisko w tej kwestii, zdecydowanie zastrzegając (użył dwukrotnie kwantyfikatora „musi”), że pedagogika jako ogólna nauka o wychowaniu

musi wspierać się na znajomości nauk o człowieku, lecz równocześnie musi pamiętać o własnym specyficznym spojrzeniu na człowieka. Najogólniej można powiedzieć, że ujmuje ona człowieka i jego wyspecjalizowane funkcje jako całość funkcjonalną głównie pod kątem stawania się, realizacji (czy samorealizacji), zwłaszcza w łączności z życiem społecznym, światem kultury i oddziaływaniem wychowawczym (Wołoszyn, 1998, s. 171-172).

Charakteryzując pedagogikę jako zespół nauk o wychowaniu, której nie sposób uprawiać bez wiedzy ontologicznej (potrzeba odniesienia się do rzeczywistości wychowawczej) i aksjologicznej (wartości i wynikające z nich cele wychowania) oraz antropologicznej (koncepcja człowieka), Marian Nowak zwraca uwagę na podstawową relację zachodzącą między teorią a praktyką oraz między sztuką a nauką i stwierdza, że pedagogika, pomimo jej silnego związku z różnymi grupami nauk jest ,przede wszystkim «nauką antropologiczną»" (Nowak, 1999, s. 225). W innym swoim dziele autor przypisuje pedagogice specyficzny charakter antropologiczny, przekonująco uzasadniając, że nie można tej nauki sprowadzać ani wyłącznie do ideologii, ani tylko do nauk empiryczno-logicznych, jako że pozostaje ona w ścisłej relacji $\mathrm{z}$ jednymi i drugimi oraz stanowi w swej dynamice miejsce swoistej dialektyki pomiędzy ideologią, teorią i praktyką, a także między naukami humanistycznymi, przyrodniczymi, społecznymi i filozoficznymi a nauką w ogólności. Po czym stwierdza, że „umieszczając człowieka i jego stawanie się w centrum, pedagogika przyjmuje specyficzny charakter nauki antropologicznej, będącej między i ponad ideologią oraz teorią" (Nowak, 2008, s. 82).

W istocie antropologia - najbardziej ogólnie rzecz ujmując - zajmująca się definiowaniem istoty człowieka i wyjaśnianiem jego roli w świecie oraz podejmująca próby rozumienia go, a także określająca kierunki rozwoju form egzystencji ludzkiej, ustawicznie poszukuje odpowiedzi na pytanie, kim/czym jest człowiek. Współcześnie rozwijając się niezwykle dynamicznie w toku spełniania swych głównych funkcji (diagnostyczna, prognostycz- 
na, instrumentalno-techniczna) pedagogika przypisana do nauk społecznych, $\mathrm{z}$ racji koncentrowania swojej uwagi na edukacji oraz wszechstronnym rozwoju człowieka we wszystkich fazach jego życia, przyjmuje de facto profil humanistyczny ${ }^{6}$. Współpracując $\mathrm{z}$ różnymi naukami współdziałającymi czerpie intensywnie z ich dorobku, spośród których antropologii przypisuje się rolę szczególnie istotną, jako że owo rozumienie człowieka wypracowane przez antropologię stanowi dla pedagogiki podstawę sine qua non.

W toku dziejów myśli ludzkiej relacje wiedzy antropologicznej i pedagogicznej przybierały rozmaitą postać, między innymi doprowadzając do wyłonienia się subdyscypliny antropologii pedagogicznej (Ablewicz, 2003, s. 146-150). Wiedza z tego zakresu została ostatnio wzbogacona za sprawą ukazania się książki Sławomira Chrosta podejmującego w niej ważne problemy z zakresu antropologii pedagogicznej rozważane z perspektywy personalizmu teistycznego (Chrost, 2020).

Podejmując kwestie poszukiwania teorii człowieka i jego sytuacji egzystencjalnej Marian Nowak stwierdza, że starożytna antropologia koncentrowała się na człowieku jako jednostce będącej specyficznym egzemplarzem swojego gatunku. Poszerzenie ujęcia człowieka o wymiar jedności i jedyności oraz podmiotowości i transcendencji nastąpiło wraz z chrześcijaństwem i dopiero w XIV w. zainteresowano się człowiekiem jako podmiotem poznającym. Renesansowy humanizm zapoczątkował pytania koncentrujące się na styku teocentrycznych i antropocentrycznych wizji świata, głosząc hasło zainteresowania się człowiekiem i tym wszystkim, co ludzkie zgodnie z lansowaną wówczas sentencją wywodzącą się od komediopisarza rzymskiego Terencjusza (195-159 p.n.e.): Homo sum; humani nihil a me alienum esse puto [Człowiekiem jestem; nic, co ludzkie nie jest mi obce]. Jednak zarówno renesans, jak i kolejne stulecie nie opracowały w tej mierze koncepcji filozoficznej. Dopiero wiek XVIII antycypował filozofię człowieka, poszukując pryncypiów natury ludzkiej za sprawą przywoływanego już w niniejszych rozważaniach Dawida Hume’a (por. Nowak, 1999, s. 297). Jednakże

w XIX w. zaznacza się wielka różnorodność podejść do zagadnienia istoty ludzkiej: od idealizmu niemieckiego, traktującego człowieka jako absolutny rozum, aż po ujęcia nauk szczegółowych, zwłaszcza humanistyki, naturalizmu i ewo-

${ }^{6}$ Pedagogika zajmująca się szeroko rozumianymi procesami edukacji jest w istocie swej przede wszystkim nauką humanistyczną i zarazem nauka społeczną. Pisałam na ten temat szerzej w innym miejscu (zob. Ostrowska, 2017). 
lucjonizmu. Te kierunki, rodząc reakcję przeciw racjonalizmowi i idealizmowi, prowadziły do powstania antropocentryzmu ontologicznego i antropologii filozoficznej jako autonomicznej dyscypliny wiedzy (u M. Schelera) (Nowak, 1999, s. 297).

Przywołany w powyższym cytacie Scheler upatrywał w antropologii filozoficznej naukę, której celem jest fundamentalne konstruowanie teoretycznych podstaw dla wszystkich nauk o człowieku i w związku z tym pisał, że

antropologia mogłaby wszystkim naukom, które mają do czynienia z przedmiotem „,człowiek”": w ujęciu przyrodniczym i medycznym, prehistorycznym, etnologicznym, historycznym i społecznym, psychologii normalnej, rozwojowej oraz charakterologii - dostarczyć ostatecznego fundamentu filozoficznej natury, a zarazem określonych, wiarygodnych celów ich badań (Scheler, 1987, s. 151).

Z kolei w poprzedzającym nasze stulecie XX wieku dominowało w filozofii, w tym zwłaszcza w antropologii filozoficznej oraz filozofii egzystencji, eksponowanie „nieokreśloności” człowieka, tudzież „otwartości” oraz „płynności” jego sposobu istnienia jako bytu, aczkolwiek podejmowano również niezbyt wyraziste oraz owocne próby konstruowania wizji człowieka jako specyficznej całości. Owym próbom niejednokrotnie przypisywano takie znamiona jak Plessnerowskie ,wrzucenie istoty ludzkiej w świat”, tudzież Heideggerowskie „wrzucenie osoby w byt”, czy Sartrowskie „wrzucenie człowieka jako bytu w świat” / ,cogito prerefleksyjne”, tudzież postmodernistyczne „wrzucenie jednostki w przygodność”. Owe stereotypy niejednokrotnie stanowiły podstawę do szkicowania obrazu człowieka jako istoty bezwolnej, niewiele mającej do powiedzenia i uczynienia w odniesieniu do własnego życia i osoby poddającej się biegowi rzeczy. Sens owego „wrzucenia człowieka w świat” przybliża w swoich rozważaniach na temat conditio humana Plessner ${ }^{8}$, przypisując istocie ludzkiej miano „człowieka ukrytego" - homo absconditus - następująco:

7 Jeden z głównych twórców fenomenologii, Edmund Husserl (1859-1938), wyrażał przekonanie, że świadomość jest intencjonalna, czyli zawsze jest świadomością czegoś, zwraca się ku czemuś oraz orzekł na ten temat, że „,człowiek jest zarazem podmiotem dla świata i przedmiotem w świecie" (cyt. za: Fellmann, 1993, s. 54).

${ }^{8}$ Problematykę conditio humana człowieka współczesnego w ujęciu aksjologicznym podejmowałam szerzej w monografii na ten temat (zob. Ostrowska, 2020). 
Jako istota wrzucona w świat człowiek jest ukryty przed samym sobą - homo absconditus. Owo pojęcie, pierwotnie określające niezgłębialną istotę Boga, wyraża naturę człowieka. Można ją ująć jedynie jako pewien sposób życia, ograniczony i umożliwiony przez jej biologiczną podstawę, sprawiający, iż człowieka nie da się bliżej określić. Dlatego też na porażkę skazane są wszystkie próby zredukowania ludzkiej natury do jakichś rzekomo decydujących czynników (Plessner, 1988, s. 120).

Natomiast początek naszego stulecia - XXI wieku - zdominowany został przez „wielką rewolucję" wspieraną przez naukę i jej osiągnięcia stawiające człowieka wobec jeszcze większych zadań do rozwiązania oraz dylematów o niespotykanej dotąd skali złożoności i problematyczności. Najczęściej tym przeobrażeniom przypisuje się miano problematyczności „rewolucji biotechnologicznej”, a wiekowi XXI odpowiednio znamię ,stulecia biotechnologicznego". Istotnie, właśnie ogromne postępy w biologii, zwłaszcza w genetyce, doprowadziły do manipulacji ludzkim genomem, w tym do klonowania zwierząt, a nawet ludzi, a także przyzwolono na badania naukowe nad embrionami ludzkimi dla celów terapeutycznych lub eugenicznych.

\section{Uwagi końcowe}

Z dokonanego przeglądu wielowiekowego dorobku nauk o człowieku wynika, że cechuje owo dziedzictwo wielka różnorodność ujęć eksplorowanych kwestii oraz ogromne w swej różnorodności bogactwo głoszonych stanowisk i poglądów ujmowanych w zróżnicowanym instrumentarium pojęciowym, a także osadzanych w najprzeróżniejszych kontekstach. Jednakże ów dorobek - jak dotąd - nie stanowi w żadnym razie wystarczającej podstawy pozwalającej na udzielenie wyczerpującej odpowiedzi na pytanie, kim jest człowiek. Złożoność i wielowymiarowość oraz potencjalność sensu tego pytania generuje bowiem rozmaite trudności, które nie tylko stanowią skomplikowane do pokonania bariery, ale wręcz uniemożliwiają udzielenie satysfakcjonującej odpowiedzi. Toteż nic dziwnego, że filozof, profesor uniwersytetów w Stuttgarcie, Heidelbergu i Monachium, który habilitował się z filozofii i pedagogiki - Robert Spaemann (1927-2018), uczestnik spotkań z Janem Pawłem II oraz założyciel Stowarzyszenia na rzecz obrony liturgii trydenckiej w Kościele katolickim, stwierdził w tej kwestii, iż: 
Fundamentalna trudność polega na tym, że wcale nie jest jasne, co ten, kto pyta: Kim jest człowiek? naprawdę chce wiedzieć i jaką odpowiedź uzna za poprawną. Czy zadowoli go chemiczny wzór struktury DNA ludzkich genów wykazujący skądinąd wielkie podobieństwo do tego, który występuje w genach świni domowej? czy chce poznać specyficzne możliwości przystosowania się ludzkiego organizmu do właściwego środowiska, niszy ekologicznej? I czy dla zrozumienia osiągnięć ludzkiej kultury wystarczy, że zrozumie ich funkcje dla przetrwania gatunku? Czy też chce tak różnorodne przecież historyczne formy samoświadomości człowieka zrozumieć na podstawie jednej generalnej zasady? A może raczej próbuje postrzegać człowieka jako pewien projekt, który rozumiemy tylko wtedy, gdy widzimy jego doskonałe spełnienie - wówczas dopiero „Ecce homo” Piłata pokazywałoby nam, kim jest człowiek? (Spaemann, 1988, s. 129).

Człowiek bowiem jako synergiczne compositum ciała i ducha, woli i intelektu, nie tyle jest, co w dynamice swego jestestwa ustawicznie staje się. Oczywiście w zależności od przyjętych kryteriów oraz wytyczonych celów eksplorowania kwestii człowieka można i trzeba wyróżniać owe sfery przynależne człowiekowi po to, aby je bardziej dogłębnie poznawać i rozumieć, jednak nie znaczą owe zabiegi rozdzielania wiodącego do swoistego rozczłonkowywania na części tego, co jest jednością i co ma sens oraz znaczenie wówczas, gdy stanowi integralną całość. Co więcej, człowiek w dynamice nieprzeniknionego bogactwa swego istnienia w sposób świadomy spełnia się w swoim jestestwie nie tylko jako „byt w sobie” oraz egzystuje jako „byt dla siebie”, lecz także istnieje jako „byt dla innych”. A przy tym człowiek, jak zauważa dominikanin, filozof, tomista, teolog oraz współtwórca lubelskiej szkoły filozoficznej, Mieczysław Albert Krąpiec (1921-2008),

jest osobowością potencjalną, a więc taką, która poprzez swe akty doskonali się, buduje i spełnia, czyli dochodzi do pełni. We wszystkich tych aktach potrzebna jest ludzkiej osobie materia; ale cele takiego „upełnienia się” są daleko pozamaterialne, a wyznaczone charakterem i prawami materii. Cele bowiem osoby są wewnętrzne, osobowe: wzbogacenie poznania, wzbogacenie miłości, uzyskanie wyższego stanu wolności w stosunku do wszelkich determinantów czy to wewnętrznych, czy zewnętrznych. Przez taki typ wewnętrznego ubogacenia się człowiek transcenduje przyrodę, chociaż jest w niej obecny poprzez swe życiowe akty, zwłaszcza akty psychiczne. Dokonuje autoafirmacji i rozwoju głównie poprzez wykształcenie w sobie sposobu bytowania „dla-osoby-drugiej”. Ostatecznie zaś aktualizuje swą osobową potencjalność poprzez mo- 
ment śmierci pojętej czynnie, kiedy to uzyskuje pełne warunki na dokonanie ostatecznej, pełnej, właśnie osobowej decyzji w stosunku do Transcendencji, która jawiła mu się w ciągu zmiennego życia raczej jako problem aniżeli narzucająca się nieodparcie rzeczywistość, w stosunku do której musiałby zająć stanowisko (Krąpiec, 1986, s. 145).

W podobnej konwencji postrzega zagadnienie wymiaru transcendentnego osoby ludzkiej teolog i filozof, twórca personalizmu uniwersalistycznego Czesław S. Bartnik (1929-2020), który przestrzega przed tendencją do redukcyjnego ujmowania człowieka, sprowadzająca go jedynie do rozumu, do umysłu oraz ujmowania w kategoriach liczby czy ilości tudzież rozumianego jako zbioru informacji i byt informatyczny - swoisty receptor informacji, budujący na ich podstawie swój świat. Tymczasem za sprawą duchowości wewnętrznej człowiek osiąga ponadmaterialność jako wyższy poziom bytowania. Wnikając w głąb ,ja" ludzkiego, w świat podmiotowy ku nieskończonemu tworzeniu podmiotowości, człowiek buduje świat na miarę swojego wnętrza. Autor przypisuje szczególne znaczenie ludzkiej transcendencji „w górę” rzeczywistości doczesnej, „,wzwyż” ku Bogu (Bartnik, 2005, s. 48).

Wyłania się zatem niemożliwy do ujęcia w wyczerpującej definicji wizerunek człowieka współczesnego rozpostartego/rozpiętego pomiędzy wieloma ekstremami, w tym zwłaszcza pomiędzy jego światem a Transcendencją, życiem a śmiercią, nauką a wiarą, cielesnością a duchowością, nicością a nieskończonością, zwątpieniem a nadzieją, szczęściem a tragedią, istoty dotkliwie doświadczającej rozdźwięku pomiędzy tym, co bywa możliwe, ale niekoniecznie zarazem jest również moralnie zasadne. I być może właśnie owa wieloraka w swej narastającej złożoności problematyczność stanowi główną przyczynę swoistego - jak można to określić - „zmęczenia człowiekiem" nauk o nim i w konsekwencji odczuwanego niedosytu rozwoju wiedzy o człowieku.

Tymczasem w obliczu doświadczania niedosytu wiedzy o człowieku coraz odważniej, ale bez należytej rozwagi lansowane są przez transhumanizm - ruch intelektualny, kulturowy oraz polityczny - możliwości i potrzeby wykorzystania nauki i techniki, w tym zwłaszcza neurotechnologii, biotechnologii i nanotechnologii, przedsięwzięcia w zakresie przezwyciężenia ludzkich ograniczeń oraz w celu - jak to bywa określane - poprawy/,ulepszania” kondycji ludzkiej. Owe kwestie dotyczące tego czy ludzie mogą lub powinni być „ulepszani” za pomocą środków biotechnologicznych i innych, wykraczające poza leczenie chorób, poddawane są dyskusji w skali światowej, w toku których stawiane jest pytanie czy, a jeśli tak, to jak daleko i w jakich 
warunkach można to czynić, aczkolwiek gubi się w owej debacie fundamentalne pytanie o to, co to znaczy być człowiekiem (zob. np. Coenen i in., 2010). Tymczasem zwolenników owego trendu „ulepszania” ludzi nie brakuje. Do najbardziej wpływowych zaliczany jest szwedzki filozof Nick Bostrom (ur. 1973), pełniący funkcję kierownika Future of Humanity Institute na Uniwersytecie Oksfordzkim. Jest on współzałożycielem organizacji patronackiej transhumanistów World Transhumanist Association (WTA) oraz autorem książki o transhumanizmie, w której zawarł program dla WTA (por. Bostrom, 2020).

Przeciwnicy transhumanizmu natomiast, do których zaliczają się między innymi Jürgen Habermas, Francis Fukuyama czy Michael Sandel, określani są mianem biokonserwatystów. Jednakże nie są oni - jak mogłaby sugerować owa nazwa - wrogami postępu biotechnologicznego. Natomiast w przeciwieństwie do transhumanistów, dla których ludzie są głównie obiektami badań empirycznych - uprzedmiatawiających człowieka oraz zagrażających jego godności i wolności - biokonserwatyści krytykując transhumanizm koncentrują uwagę przede wszystkim wokół zastrzeżeń dotyczących kwestii etycznych i moralnych. Uważany za jednego z najbardziej wpływowych filozofów i socjologów współczesnego świata Jürgen Habermas (ur. 1929), przez wiele lat skupiający swoją uwagę na fundamentalnych zagadnieniach społecznych, takich jak proces komunikacji oraz rola języka w kształtowaniu europejskiego pojęcia racjonalności, na początku XXI wieku dokonał zwrotu ku tematyce religijnej i postuluje dopuszczenie religii do grona filarów nowożytnej racjonalności, albowiem stanowi ona fundament dla etyki, co argumentuje następująco: „Tradycje religijne dysponują szczególną mocą artykulacyjną i intuicjami moralnymi, zwłaszcza dotyczącymi delikatnych form wspólnego życia ludzi. Ten potencjał czyni język religii poważnym kandydatem do tego, by służyć za nośnik możliwych treści prawdziwościowych" (Habermas, 2012, s. 116-117). Wygłaszając przemówienie w związku z otrzymaniem Nagrody Pokojowej Niemieckich Księgarzy w 2001 roku wyraził następującą wątpliwość: „Czy pierwszy człowiek, który w e d ł u g wła s n e g o u p o d o b a n i a określi, jaki ma być z natury inny człowiek, nie zniszczy siłą rzeczy owych jednakowych wolności, które przysługują ludziom równym z urodzenia, aby zagwarantować ich różność?" (Habermas, 2002, s. 21) $)^{9}$.

${ }^{9}$ Pełny tekst tego przemówienia wygłoszonego w Kościele św. Pawła we Frankfurcie zawarto w wydanej kilka lat później książce Habermasa (Habermas, 2003). 
Niektórzy transhumaniści przewidują, że człowiek może w końcu przekształcić się w istotę o znacznie rozszerzonych zdolnościach, ,usprawiedliwiających” stan bycia nazywany ,postczłowiekiem”. Tymczasem amerykański politolog, filozof polityczny i ekonomista japońskiego pochodzenia Francis Fukuyama (ur. 1952), który znany jest z ogłoszenia ongiś „końca historii”, przewiduje, że biotechnologia może doprowadzić do „końca człowieka", którego zastąpią osobniki genetycznie zmodyfikowane będące zgoła innymi istotami, niż istoty ludzkie, które dotychczas znamy. Podziela on pogląd biokonserwatystów głoszących, iż angażowanie się w intencjonalne modyfikowanie genów człowieka stanowi ryzyko zniszczenia natury ludzkiej. Toteż każda próba zmiany naturalnego stanu człowieka nie powinna być zastosowana, dopóki nie oceni się ryzyka z tym związanego (Fukuyama, 2004, s. 173n).

Człowiek XXI wieku ma wprawdzie niespotykane dotąd możliwości przekraczania najdalszych granic otaczającej rzeczywistości nawet bez konieczności fizycznego przemieszczania się poza własne miejsce zamieszkania, czy poza terytorium państwowe oraz kontynentalne. Ma również ogromny potencjał własnego rozwoju, doskonalenia się, wzbogacania swojej osobowości. Jednakże w rezultacie intensywnego rozwoju cywilizacji i współczesnych technologii paradoksalnie okazuje się, że coraz bardziej doskonalony, unowocześniany oraz wzbogacany świat zewnętrzny człowieka, poszerzając się do niewyobrażalnych rozmiarów, swoim ciężarem i wielkością niejako przytłacza i wręcz brutalnie minimalizuje świat wewnętrzny istoty ludzkiej. Taki stan rzeczy przyczynia się do wyjaławiania i pozbawiania człowieka głębi, destruując tym samym możliwości autentycznego poznawania siebie samego i rozumienia siebie oraz doskonalenia conditio humana, czyli tego co z perspektywy istoty człowieczeństwa jest najistotniejsze. W następstwie owego „kurczenia się” życia wewnętrznego ludzi pojawia się tendencja do upraszczania i spłycania problemów współczesnych, otaczającego świata i istoty człowieka. Zatem imponujący rozwój cywilizacji będący dziełem ludzkim i mający uczynić życie ludzkie mniej uciążliwym, dogodnym i szczęśliwym wpędził człowieka w pułapkę dylematyczności, na rozstaje dróg własnego człowieczeństwa ${ }^{10}$. Ów stan rzeczy stawia przed nauką i edukacją wyzwania, którym w obliczu rodzących się dylematów niełatwo będzie stawić czoła a przy tym generuje liczne kluczowe problemy ad deliberandum.

${ }^{10} \mathrm{Z}$ innej perspektywy owe rozbieżności rozważałam w opracowaniu na temat problemów edukacji wobec globalizacji (zob. Ostrowska, 2000). 
Przeprowadzone w artykule rozważania koncentrowały główną uwagę wokół kwestii antropologii i pedagogiki w kręgu wiedzy nauk o człowieku. $\mathrm{W}$ rezultacie owych dociekań ujmowanych z perspektywy priorytetowych problemów teraźniejszości i wyzwań przyszłości, z jednej strony wyłania się zróżnicowane bogactwo zasobów wiedzy na temat człowieka i jego świata. $Z$ drugiej strony natomiast uwyraźniają się narastające oczekiwania dotyczące wzbogacania istniejącej wiedzy na ten temat. Niewątpliwie rozwój zasobów owej wiedzy znacznie utrudnia ustawiczne ewoluowanie złożonej i rozległej problematyki na temat fenomenu człowieka sytuowanego w wielorako zróżnicowanej dynamicznie zmieniającej się rzeczywistości. Ponadto nie sprzyja skutecznemu wychodzeniu naprzeciw temu wyzwaniu interdyscyplinarne rozproszenie dotychczasowej wiedzy na temat człowieka.

Niemniej, inspirujący wymiar owych przedsięwzięć ma wszakże swoje źródło nie tylko w dotkliwie doświadczanych występujących lukach wiedzy na ten temat, lecz nade wszystko wzbudza zainteresowanie ta problematyka dlatego, że dotyczy ludzkości i każdego człowieka z osobna, toteż tym bardziej motywuje do niekończących się dociekań poznawczych. Koncentruje bowiem uwagę na człowieku jako istocie racjonalnej wyrażającej się najwyższym rozwojem psychiki i życia społecznego, sposobami formułowania myśli oraz bogactwem posługiwania się językiem, a także wyrażania uczuć, jak również różnorodnością rodzajów ludzkich zachowań, w tym posiadaniem kultury oraz zdolności do jej tworzenia, tudzież do przeżywania idei i norm moralnych, zwłaszcza wartości religijnych związanych z sacrum (Mariański, 2017, s. 9-20).

\section{Bibliografia}

Ablewicz, K. (2003). Antropologia pedagogiczna. W: T. Pilch (red.), Encyklopedia pedagogiczna XXI wieku, t. I (s. 146-150). Warszawa: „Żak”.

Ajdukiewicz, K. (1960). Język i poznanie, t. I. Warszawa: PWN.

Augustyn (2000). Wyznania. Tłum. Z. Kubiak. Kraków: Znak.

Bartnik, Cz. S. (2005). Osoba ludzka jej wymiar społeczny i transcendentny. Ethos, 18(1/2), 41-49.

Bostrom, N. (2020). Transhumanism. From Ancestors to avatars. Cambridge: University Press [The Transhumanist FAQ. A General Introduction, version 2.1, World Transhumanist Association. Pobrano 12.12.2021 z: http://www.transhumanism.org/resources/FAQv21.pdf.] 
Chrost, S. (2020). Antropologia pedagogiczna perspektywie personalizmu teistycznego. Warszawa: Difin.

Coenen, C., Gammel, S., Heil, R., Woyke, A. (eds.). (2010). Die Debatte über «Human Enhancement». Historische, philosophische und ethische Aspekte der technologischen Verbesserung des Menschen. Bielefeld: transcript Verlag.

Fellmann, F. (1993). Świat przeżywany i świat duchowy. Fenomenologiczne pojęcie świata a protestancka filozofia kultury. Tłum. M. Łukasiewicz. W: Z. Krasnodębski, K. Nellen (red.), Świat przeżywany. Fenomenologia i nauki społeczne (s. 48-102). Warszawa: PIW.

Fukuyama, F. (2004). Koniec człowieka. Konsekwencje rewolucji biotechnologicznej. Tłum. B. Pietrzyk. Kraków: Znak.

Gadamer, H.-G. (2004). Prawda i metoda. Zarys hermeneutyki filozoficznej. Tłum. B. Baran. Warszawa: PWN.

Gadamer, H.-G. (2008). Teoria, etyka, edukacja. Eseje wybrane. Tłum. P. Dehnel, A. Przyłębski, A. Mergler, P. Sosnowska. Warszawa: Wydawnictwo UW.

Habermas, J. (2002). Wierzyć i wiedzieć. Tłum. M. Łukasiewicz. Znak, 568(9), 8-21. Habermas, J. (2003). Przyszłość natury ludzkiej. Czy zmierzamy do eugeniki liberalnej?. Tłum. M. Łukasiewicz. Warszawa: Scholar.

Habermas, J. (2012). Między naturalizmem a religia. Tłum. M. Pańków. Warszawa: PWN.

Hume, D. (1963). Traktat o naturze ludzkiej, t. I. Tłum. Cz. Znamierowski. Warszawa: PWN.

Ingarden, R. (1987a). Książeczka o człowieku. Kraków: Wydawnictwo Literackie.

Ingarden, R. (1987b). Spór o istnienie świata, t. I. Tłum. D. Gierulanka. Warszawa: PWN.

Jaspers, K. (1990). Człowiek. Tłum. D. Lachowska. W: idem, Filozofia egzystencji. Wybór pism. Warszawa: PIW.

Jaspers, K. (1999). Wiara filozoficzna wobec objawienia. Tłum. G. Sowiński. Kraków: Znak.

Kierkegaard, S. (1996). Pojęcie lęku, t. I. Tłum. A. Dajkowska. Warszawa: PWN.

Krapiec, M. A. (1986). Człowiek i prawo naturalne. Lublin: TN KUL.

Maliszewski, K. (2016). Pedagogika filozoficzna jako ruch transdyscyplinarny. $N a$ uki o Wychowaniu. Studia Interdyscyplinarne, 2(1), 15-28.

Marcel, G. (1962). Być i mieć. Tłum. P. Lubicz. Warszawa: PAX.

Marcel, G. (1984). Homo viator. Wstęp do metafizyki nadziei. Tłum. P. Lubicz. Warszawa: PAX.

Marcel, G. (1987). Dziennik metafizyczny. Tłum. E. Wende. Warszawa: PAX.

Marcel, G. (1995). Tajemnica bytu. Tłum. M. Frankiewicz. Kraków: Znak. 
Mariański, J. (2017). Godność ludzka jako nowy paradygmat w socjologii moralności. Uniwersyteckie Czasopismo Socjologiczne, 21(4), 9-20.

Nowak, M. (1999). Podstawy pedagogiki otwartej. Ujęcie dynamiczne w inspiracji chrześcijańskiej. Lublin: RW KUL.

Nowak, M. (2008). Teorie i koncepcje wychowania. Warszawa: WAiP.

Ostrowska U. (2017). Aksjologia pedagogiczna - subdyscyplina naukowa pedagogiki (in statu nascendi). Roczniki Pedagogiczne, 9(2), 11-30.

Ostrowska, U. (2000). Etos języka edukacji w kontekście problemów globalizacji. W: U. Ostrowska i A. M. de Tchorzewski (red.), Etos pedagogiów i edukacji wobec problemów globalizacji (s. 179-190). Bydgoszcz-Olsztyn: Wydawnictwo Akademii Bydgoskiej im. Kazimierza Wielkiego.

Ostrowska, U. (2020). Coditio humana człowieka wspótczesnego. W trosce o człowieczeństwo z perspektywy aksjologicznej. Gorzów Wielkopolski: Wydawnictwo Akademii im. Jakuba z Paradyża.

Pascal, B. (2003). Myśli oraz Rozprawa o kondycji możnych. Modlitwa o dobry początek Rozprawa o namiętności miłości. Tłum. T. Boy-Żeleński. Kraków: Zielona Sowa.

Plessner, H. (1988). Homo absconditus. W: idem, Pytanie o conditio humana. Tłum. Z. Krasnodębski (s. 107-121). Warszawa: PIW.

Plessner, H. (1994). Władza a natura ludzka. Esej o antropologii światopogladu historycznego. Tłum. E. Paczkowska-Łagowska. Warszawa: PWN.

Scheler, M. (1987). Pisma z antropologii filozoficznej i teorii wiedzy. Tłum. A. Węgrzecki. Warszawa: PWN.

Schweitzer, A. (1981). Z mojego życia.... Tłum. I. Salomon. Kraków: PAX.

Spaemann, R. (1988). O pojęciu natury ludzkiej. W: K. Michalski (red.), Człowiek w nauce wspótczesnej. Rozmowy w Castel Gandolfo. Tłum. Z Krasnodębski. Kraków: Wydawnictwo Znak.

Wołoszyn, S. (1998). Nauki o wychowaniu w Polsce XX wieku. Próba syntetycznego zarysu na tle powszechnym. Kielce: Strzelec. 